This item was submitted to Loughborough's Research Repository by the author.

Items in Figshare are protected by copyright, with all rights reserved, unless otherwise indicated.

\title{
Ionic conducting properties and fuel cell performance developed by band structures
}

PLEASE CITE THE PUBLISHED VERSION

https://doi.org/10.1021/acs.jpcc.8b11914

\section{PUBLISHER}

(c) American Chemical Society (ACS)

\section{VERSION}

AM (Accepted Manuscript)

\section{PUBLISHER STATEMENT}

This document is the Accepted Manuscript version of a Published Work that appeared in final form in The Journal of Physical Chemistry C, copyright @ American Chemical Society after peer review and technical editing by the publisher. To access the final edited and published work see https://doi.org/10.1021/acs.jpcc.8b11914

\section{LICENCE}

CC BY-NC-ND 4.0

\section{REPOSITORY RECORD}

Ganesh, K. Sivajee, Baoyuan Wang, Jung-Sik Kim, and Bin Zhu. 2019. "Ionic Conducting Properties and Fuel Cell Performance Developed by Band Structures". figshare. https://hdl.handle.net/2134/37338. 


\title{
Ionic conducting properties and fuel cell performance developed by band structures
}

\author{
K. Sivajee Ganesh ${ }^{1}$, Baoyuan Wang ${ }^{1 * *}$, Jung-Sik Kim ${ }^{3}$, Bin Zhu1,2,3* \\ 1. Hubei Collaborative Innovation Center for Advanced Organic Chemical Materials, Key Laboratory of Ferro \& \\ Piezoelectric Materials and Devices of Hubei Province, Faculty of Physics and Electronic Science, Hubei \\ University, Wuhan, Hubei 430062, P. R. China. baoyuanw@163.com \\ 2. Faculty of Materials Science and Chemistry, China University of Geosciences, 388 Lumo Road, Wuhan 430074, \\ China. \\ 3. Department of Aero \& Auto Engineering, Loughborough University, Ashby Road, Loughborough, UK, LE11 \\ 3TU.b.zhu@,lboro.ac.uk
}

\begin{abstract}
The layer structure transition metal oxides have good triple $\mathrm{H}^{+} / \mathrm{O}^{2-} / \mathrm{e}^{-}$charge transport which can promote redox reactions and enhance fuel cell performance. This work has developed ionic transport property based on the layer structure $\mathrm{LiCoO}_{2}(\mathrm{LCO})$ by tuning energy band structure with $\mathbf{M g}$ doping also applied for the electrolyte in high-performance lowtemperature solid oxide fuel cells (LT-SOFCs). $\mathrm{Mg}$ doped $\mathrm{LiCoO}_{2}$ exhibited a hexagonal layered structure with $\mathrm{R} 3 \mathrm{~m}$ space group. By doping the $\mathrm{LiCoO}_{2}$ band gap was reduced from $2.65 \mathrm{eV}$ to $2.24 \mathrm{eV}$. Electrochemical impedance analysis revealed Mg-doped LCO (LMCO) reducing significantly the polarization loss (charge transfer resistance) from 0.85 to $0.5 \Omega \mathrm{cm}^{2}$ at $600{ }^{\circ} \mathrm{C}$; the power output of the fuel cell devices improved from $0.5 \mathrm{~W} / \mathrm{cm}^{2}$ to $0.7 \mathrm{~W} / \mathrm{cm}^{2}$ resulting also in better operation durability. Various characterizations on structural and electrochemical properties were conducted. The mechanism was further discussed relation with the band structures.
\end{abstract}

Key words: $\mathrm{LiCoO}_{2}, \mathrm{Mg}$ doped $\mathrm{LiCoO}_{2}$, Layered structure, Band structure, Fuel cell, Mixed ionic and electronic conduction.

\section{Introduction}

One of the critical hindrances in the state of the art SOFC's is the use of cathode materials that perform poorly at the electrochemical reduction of oxygen at low temperatures (LT) and 
degrade over time under operating conditions. ${ }^{1-2}$, In addition, lack of ionic conducting electrolyte material is another critical issue on LT-SOFC R\&D. In recent developments, the triple charge of $\mathrm{H}^{+} / \mathrm{O}^{2-} / \mathrm{e}^{-}$transportation in composite materials have demonstrated very successful LT-SOFC performances. ${ }^{3}$ In this context Co based mixed ionic-electronic conductors (MIEC's) like $\mathrm{SrCo}_{0.7} \mathrm{Nb}_{0.1} \mathrm{Fe}_{0.2} \mathrm{O}_{3-\delta},{ }^{4} \mathrm{Ba}_{0.5} \mathrm{Sr}_{0.5} \mathrm{Co}_{0.8} \mathrm{Fe}_{0.2} \mathrm{O}_{3-\delta},{ }^{5} \mathrm{Sm}_{0.5} \mathrm{Sr}_{0.5} \mathrm{CoO}_{3}{ }^{6}$ $\mathrm{La}_{1-\mathrm{x}} \mathrm{Sr}_{\mathrm{x}} \mathrm{Co}_{1-\mathrm{y}} \mathrm{Fe}_{\mathrm{y}} \mathrm{O}_{3},{ }^{7} \mathrm{BaCo}_{0.7} \mathrm{Fe}_{0.22} \mathrm{Y}_{0.08} \mathrm{O}_{3-\delta},{ }^{8}$ and $\mathrm{BaCo}_{0.4} \mathrm{Fe}_{0.4} \mathrm{Zr}_{0.1} \mathrm{Y}_{0.1} \mathrm{O}_{3-\delta},{ }^{9}$ have been widely investigated because the Co produces low polarization resistance, as well as increasing both ionic and electronic conductivities in comparison with other SOFCs. All these materials were reported as quite good functional materials for LT-SOFC's with oxygen and proton ion conducting electrolytes. A summary on previously reported for the functional materials with mixed ionic $\left(\mathrm{O}^{2-} / \mathrm{H}^{+}\right)$- electronic $\left(\mathrm{e}^{-}\right)$conducting properties offer promising performance for application in low-temperature solid oxide fuel cells (LT-SOFC). Recently, the family of lithiated transition metal oxides has attracted much attention to be used as promising functional materials with MIEC (mixed ionic and electronic conduction) property for LT-SOFC's. Layer structured $\mathrm{LiCo}_{0.5} \mathrm{Al}_{0.5} \mathrm{O}_{2}$ (LCAO) has been already proven to have high proton conductivity, $0.1 \mathrm{~S} / \mathrm{cm}$ at $500{ }^{\circ} \mathrm{C}$, which was used as potential electrolyte in fuel cells and as a cathode material in Li-ion batteries as well as a proton conducting material upon $\mathrm{Li}^{+} / \mathrm{H}^{+}$exchange reactions in fuel cell testing conditions in the presence of $\mathrm{H}_{2} \cdot{ }^{10,11}$ However, the material has its own structural limitation i.e. the rhombohedral structure lead to collapse upon delithiation (> $0.5 \mathrm{Li}$ ) ions, which reduces the cell cyclability, thereby, limiting the commercial applicability. On the other hand, a high amount of cobalt in LCO, generally, unstable at higher operating temperatures due to its large thermal co-efficient behavior and also increases basic material cost. ${ }^{12}$ Alternatively, attempts were made to substitute some proportions of Co site with $\mathrm{Ti}, \mathrm{Zr}$, $\mathrm{Mn}, \mathrm{Mg}$ etc. ${ }^{13-16}$ transition dopants in LCO layered structure. Recently, Zhu et.al, ${ }^{17}$ reported $\mathrm{LiNiFeO}_{2}$ used as the semiconductor-ionic composites used for advanced LT-SOFCs, Zhang et.al, ${ }^{18}$ reported the use of $\mathrm{LiNi}_{0.79} \mathrm{Co}_{0.2} \mathrm{Zn}_{0.01} \mathrm{O}_{2}$ cathodes in SDC electrolyte based SOFC's and presented a peak power density up to $1.32 \mathrm{~W} / \mathrm{cm}^{2}$ at $650{ }^{\circ} \mathrm{C}$ with hydrogen as fuel. In his case, the improvement in the power densities was attributed to the use of partial substitution of $\mathrm{Li}^{+}$ at $\mathrm{Ni}^{2+}$ sites introduces a hole in the form of $\mathrm{Ni}^{3+}$ or $\mathrm{O}^{2-}$ to keep the charge neutrality, thereby increasing its electrical conductivity. On the other hand, $\mathrm{LiNi}_{0.79} \mathrm{Co}_{0.2} \mathrm{Zn}_{0.01} \mathrm{O}_{2}$ introduces the extrinsic proton conduction pathways between two adjacent $\mathrm{NiO}$ layers forming a unique layered structure through lithium intercalation. Lan et al. ${ }^{10}$ have also reported higher proton conductivity using similarly layered oxide LCAO which suggested to substitute Co sites, maybe with the non-transition metals ( $\mathrm{Al}, \mathrm{Ca}$ and $\mathrm{Mg}$ ) with fixed oxidation states. Tukamoto 
et.al. ${ }^{19}$ reported that substitution of $\mathrm{Mg}^{2+}$ for $\mathrm{Co}^{3+}$ greatly enhanced the structural stability as well as the electronic conductivity of the pristine $\mathrm{LiCoO}_{2}$ due to enlargement of inter-layer space (is called pillar effect) thus reduces the Li-ion transport resistance so that a significant mass of lithium ions are extracted from/into the host matrix. Based on our previous studies on RF magnetron sputter deposited pristine, $\mathrm{Ti}$ and $\mathrm{Zr}$ doped $\mathrm{LiCoO}_{2}$ thin films as a cathode material in Li-ion batteries, ${ }^{20,21}$ the present work are to extend $\mathrm{LiCoO}_{2}$ application for SOFCs. It may be noticed that the layer structure materials exhibit excellent proton conduction, i.g. the best proton conductivity $0.1 \mathrm{~S} / \mathrm{cm}$ at $500{ }^{\circ} \mathrm{C}$ demonstrated for LCAO in the interlayer spaces used as the electrolyte materials under the fuel cell condition. ${ }^{3,10,}$ the main scope of this study is to develop further the layer structured material advantages by doping to tune band structures and further constructing heterostructure materials with ionic conductors to enhance the ionic conduction. $^{22-25}$ We have demonstrated the feasibility of changing semiconductor band structures by doping to readily make strong impact on the electrical properties and the overall device's electrochemical performance of the SOFC's. By doping to tune the band structure and material properties, we can also improve the durability of the LCO based membrane fuel cells.

\section{Experimental}

\subsection{Sample preparation and Fuel cell fabrication}

The pristine $\mathrm{LiCoO}_{2}$ powders are prepared by Sol-Gel method: $\mathrm{LiNO}_{3}$, $\mathrm{Co}\left(\mathrm{NO}_{3}\right)_{2} \cdot 6 \mathrm{H}_{2} \mathrm{O}$ and ethylene glycol with a molar ratio of 1:1:2 were dissolved in deionised water. The entire process was carried out under continues stirring at $100{ }^{\circ} \mathrm{C}$ until fully removal of the solvent. Then the resulting sol was dried at $130{ }^{\circ} \mathrm{C}$ to get rid of the impregnated water and finally calcinated at $800{ }^{\circ} \mathrm{C}$ for $4 \mathrm{~h}$ to produce $\mathrm{LiCoO}_{2}$ powder. The preparation process of $\mathrm{LiMg}_{0.1} \mathrm{Co}_{0.9} \mathrm{O}_{2}$ powders is similar with that of $\mathrm{LiCoO}_{2}$. In order to incorporate the $\mathrm{Mg}$, a required amount of $\mathrm{Mg}\left(\mathrm{NO}_{3}\right)_{2} \cdot 6 \mathrm{H}_{2} \mathrm{O}$ was deliberately added the precursory solution.

The $\mathrm{Ce}_{0.8} \mathrm{Sm}_{0.2} \mathrm{O}_{2}$ powder is prepared by Sol-Gel method: $\mathrm{Ce}\left(\mathrm{NO}_{3}\right)_{2} \cdot 6 \mathrm{H}_{2} \mathrm{O}$ and $\mathrm{Sm}$ $\left(\mathrm{NO}_{3}\right)_{2} \cdot 6 \mathrm{H}_{2} \mathrm{O}$ with a molar ratio 0.8:0.2 were dissolved in deionised water. Then, the prepared $\mathrm{Na}_{2} \mathrm{CO}_{3}$ solution (metal to carbonate ratio of 1:2) was added as a precipitant under continuous stirring at $80^{\circ} \mathrm{C}$ for $6 \mathrm{~h}$, thereafter the excess carbonate was removed by vacuum filtration and washed three times and dried in the oven at $120^{\circ} \mathrm{C}$ overnight. The dried samples were ground and calcinated at $800{ }^{\circ} \mathrm{C}$ for $4 \mathrm{~h}$ to produce $\mathrm{Ce}_{0.8} \mathrm{Sm}_{0.2} \mathrm{O}_{2}$. 
The fuel cell was fabricated by dry pressing method. LCO-SDC and LMCO-SDC composite materials were sandwiched between two pieces of NCAL $\left(\mathrm{Ni}_{0.8} \mathrm{Co}_{0.15} \mathrm{Al}_{0.05} \mathrm{LiO}_{2}\right)$ coated $\mathrm{Ni}$ foam, then pressed under $10 \mathrm{MPa}$ to form the symmetrical configuration of $\mathrm{Ni}$ NCAL/LCO-SDC/Ni-NCAL and Ni-NCAL/LMCO-SDC/Ni-NCAL. The active area and thickness of these cells is $0.64 \mathrm{~cm}^{2}$ and $1.9 \mathrm{~mm}$, respectively.

\subsection{Physical characterization}

The crystal structure of these prepared samples was studied by a Bruker D8 X-ray diffractometer (XRD, Germany, Bruker Corporation) with $\mathrm{CuK}_{\alpha}$ radiation $\left(\lambda=1.5406 \mathrm{~A}^{\circ}\right)$ in the diffraction angle $(2 \theta)$ range $10^{\circ}-90^{\circ}$ with a scan speed of 0.03 degree/sec. The peak positions were determined precisely using the RAYFLEX-Analyze software. The morphologies of samples were investigated by field emission scanning electron microscope (FE-SEM, JEOL, JSM7100F) equipped with an energy dispersive spectrometer (EDS). To further characterize the microstructure, ultra high resolution transmission electron microscope (HR-TEM) was performed using a FEI Tecnai G2 F30 field-emission microscope operating under an accelerating voltage $300 \mathrm{KV}$. X-ray photoelectron spectroscopic (XPS) studies were performed to analyze the oxidation state of the chemical composition using VG Multilab-2000 with $\mathrm{Al} \mathrm{K} \alpha$ anode $(1486.6 \mathrm{eV})$ in ultrahigh vacuum $\left(5 \times 10^{-10} \mathrm{mbar}\right)$.

\subsection{Optical and Electrochemical characterization}

The optical reflectance study was carried out with a UV-Vis-IR spectrometer (Model: SHIMADZU 3600) in the wavelength range $300-2500 \mathrm{~nm}$ at room temperature. The electrochemical characterization of fuel cells was carried out by a computerized instrument (IT8511+, Ed, electronics co., LTD). Here the hydrogen was used as fuel and air as an oxidant with a flow rate of $80-90 \mathrm{ml} \mathrm{min}^{-1}$ and $120-150 \mathrm{ml} \mathrm{min}^{-1}$ under 1 atm, respectively. Electrochemical impedance spectrum (EIS) analysis was conducted by an electrochemical workstation (CHI-660D) under open circuit voltage with a $10 \mathrm{mV}$ AC signal over the frequency range of $0.1-10^{5} \mathrm{~Hz}$. 


\section{Results and discussion}

\subsection{Microstructural Properties}

The XRD patterns of SDC, LCO, LMCO, LCO-SDC and LMCO-SDC powders sintered at $800{ }^{\circ} \mathrm{C}$ for $4 \mathrm{~h}$ are shown in Fig. 1. The characteristic diffraction peaks of LCO and LMCO can be indexed as a layered structure based on a hexagonal $\alpha-\mathrm{NaFeO}_{2}$ structure with $\mathrm{R} 3 \mathrm{~m}$ space group and no appreciable impurity peaks were observed for the Mg-doped LCO sample, these results are well matched with the standard JCPDS data (Card number: 750532). LMCO reveals well split characteristic peaks $\left(\begin{array}{lll}0 & 0 & 6\end{array}\right) /\left(\begin{array}{lll}0 & 1 & 2\end{array}\right)$ and $\left(\begin{array}{lll}1 & 0 & 8\end{array}\right) /\left(\begin{array}{lll}1 & 1 & 0\end{array}\right)$ in comparison with $\mathrm{LCO}$, which indicates that there is a dimensionally stable structure with a highly ordered array of $\mathrm{Co}$ and $\mathrm{O}_{2}$ atoms in the layered structure. From XRD results, LCO and LMCO hexagonal lattice parameters obtained are: $a=2.812, c=14.031(c / a=4.98)$ and $a=2.819$, $c=14.090(c / a=4.99)$ respectively; the slight increase of LMCO lattice constants and $c / a$ ratio in comparison with LCO is attributed to the bigger ionic radii of $r\left(\mathrm{Mg}^{2+}\right)\left(=0.72 \mathrm{~A}^{\circ}\right)$ than the ionic radii of $\mathrm{r}\left(\mathrm{Co}^{3+}\right)\left(=0.525 \mathrm{~A}^{\circ}\right)$, therefore $\mathrm{Mg}^{2+}$ is incorporating into Co and the $\mathrm{LiCoO}_{2}$ layer should mainly increase the inter-slab spacing of the layered structure (Fig. 2), ${ }^{26-28}$ thus helping to facilitate the hasty intercalation of $\mathrm{Li}^{+} / \mathrm{H}^{+}$and oxide ions into the hexagonal host matrix under fuel cell conditions. As a result these compounds are expected to possess higher ionic conductivity and better electrochemical performance after $\mathrm{Mg}$ doping. Moreover, the LCO-SDC and LMCO-SDC composite diffraction peaks indicate the co-existence of individual phases for LCO, LMCO, and SDC. No additional diffraction peaks and no distinct shift can be observed in the diffraction patterns, indicating that no other chemical phases were formed from interactions between the LCO, LMCO, and SDC. LMCO-SDC and LCO-SDC composite being yielded as chemically stable materials is critical for the stability of the assembled fuel cell device.

FE-SEM of the LCO, LMCO, SDC, LCO-SDC and LMCO-SDC powders sintered at 800 ${ }^{\circ} \mathrm{C}$ is given in Fig. 3. Fig. 3 (a) and (b) shows a well-crystallized hexagonal shape for both LCO and LMCO which can be seen without displaying agglomeration. The morphologies of LCO and LMCO look very similar, although the particle size (about $200 \mathrm{~nm}$ ) of LMCO is smaller than that of LCO (about $300 \mathrm{~nm}$ ). It is known that the small particles can have a large surface active area with better contact of the electrode and electrolyte composite. ${ }^{29} \mathrm{Fig} .3$ (c) shows the SDC electrolyte is dense except minor closed pores, and the LMCO-SDC composite displays good interconnectivity between particles, as well as showing a greater number of conductive 
pathways being present when compared with LCO-SDC composite shown in Fig. 3 (d) and (e), and the average grain size is much smaller than $1 \mu \mathrm{m}$. Fig. 3 (f). shows the cross-sectional microstructure of the fuel cell consisting of a $1.2 \mathrm{~mm}$ dense LMCO-SDC composite material and 340-360 $\mu \mathrm{m}$ NCAL-coated Ni foam on both sides of the composite material and shows indepth the resulting Ni-NCAL/LMCO-SDC/Ni-NCAL nanocomposite SOFC. Furthermore, TEM was utilized to characterize the microstructure of the LCO-SDC and LMCO-SDC composites. LMCO-SDC composite shows (Fig. 3 (h)) homogeneously distributed with good contact between the particles then LCO-SDC composite (Fig $3(\mathrm{~g})$ ). This behaviour due to the effect of $\mathrm{Mg}$ doping dispersed in the composite, which constrain the accumulation of the composite material grains. Fig 3 (i) shows the well-defined lattice fringes, confirming the high crystallinity and the crystal size of the LMCO and SDC is very fine. As can be seen from Fig 3 (i), the measured crystal lattice fringes d-spacing of LMCO was approximately $0.23 \mathrm{~nm}$ which correspond to the (llllll 006 ) plane of hexagonal phase (R3m space group) and $0.31 \mathrm{~nm} \mathrm{~d}$ spacing is ascribed to the $\left(\begin{array}{lll}1 & 1 & 1\end{array}\right)$ plane of SDC, which shows a good agreement with the XRD results as shown in Fig. 1. As Figure $S_{1}$ in the supporting information shows, the EDS elemental mapping of LMCO-SDC composite material reveals the uniform distribution of $\mathrm{Co}, \mathrm{Mg}, \mathrm{Ce}$, $\mathrm{Sm}$, and $\mathrm{O}$, indicating the formation of LMCO-SDC composite material; this kind of composite can offer the possibility of rapid oxygen and proton transport and sufficient active sites for ORR.

The presence of elements and their oxidation states in LCO-SDC and LMCO-SDC composite were further examined by XPS technique. The survey spectrum of composite fuel cells exhibited characteristic photoelectron emissions at binding energies (BEs) corresponding to $\mathrm{Li}, \mathrm{Mg}, \mathrm{Co}, \mathrm{Ce}, \mathrm{Sm}, \mathrm{C}$ and $\mathrm{O}$ elements, shown in supporting information Figure $\mathrm{S}_{2}$. Fig. 4 (a) and (b) shows the BE peak for Li $1 \mathrm{~s}$ at $54 \mathrm{eV}$ and Co 2 p core peaks were detected as two parts, Co $2 p_{3 / 2}$ and Co $2 p_{1 / 2}$ at 779.4 and $794.7 \mathrm{eV}$ BEs, respectively. This demonstrates that the oxidation state is $\mathrm{Co}^{3+}$ in the LCO-SDC composite material. The LMCO-SDC composite material exhibits the core peaks for Co $\left(2 \mathrm{p}_{3 / 2}\right.$ at 779.56 and $2 \mathrm{p}_{1 / 2}$ at $\left.794.86 \mathrm{eV}\right)$ slightly shifted to a higher binding energy than LCO-SDC composite material, indicating the possible partial oxidation of $\mathrm{Co}^{3+}$ to $\mathrm{Co}^{4+}$. The presence of $\mathrm{Co}^{3+}$ and $\mathrm{Co}^{4+}$ could facilitate the oxygen reduction and evolution reactions. ${ }^{30,31} \mathrm{Mg} 1 \mathrm{~s}$ BE peak detected at $1303.4 \mathrm{eV}$ is assigned to the $\mathrm{Mg}^{2+}$ and it confirms the existence of $\mathrm{Mg}^{2+}$ in the LMCO-SDC composite material shown in Fig. 4 (c). The peaks in the spectrum of Ce $3 \mathrm{~d}$ were observed in different ionic states such as $\mathrm{Ce}^{3+}(\mathrm{BEs}$ are $3 \mathrm{~d}_{5 / 2}$ at 878 and $3 \mathrm{~d}_{3 / 2}$ at $\left.896 \mathrm{eV}\right)$ and $\mathrm{Ce}^{4+}\left(\mathrm{BEs}\right.$ are $3 \mathrm{~d}_{5 / 2}$ at 898.3 and $3 \mathrm{~d}_{3 / 2}$ at $916.6 \mathrm{eV}$ ) shown in Fig. 4 (d). Fig. 4 (e) shows the $\mathrm{Sm} 3 \mathrm{~d}\left(3 \mathrm{~d}_{5 / 2}\right.$ at 1080.5 and $3 \mathrm{~d}_{3 / 2}$ at $\left.1107.4 \mathrm{eV}\right)$ peaks 
which confirm the doping of $\mathrm{Sm}$ in $\mathrm{CeO}_{2}$ nanomaterial. ${ }^{32}$ The $\mathrm{O}$ 1s photoemission peaks display the BEs at 528.6 and $531 \mathrm{eV}$ for all the composite cells, and observed the higher intensity for $\mathrm{Mg}$-doped composite material than the $\mathrm{Mg}$-free composite material, which means that a stronger interaction occurred between the composite catalysts and adsorbed oxygencontaining species due to the synergistic effect, which is an advantage for the process of oxygen reduction reactions shown in Fig. 4 (f). Hence, these XPS and EDS observations confirm the formation of LCO-SDC and LMCO-SDC composite materials.

\subsection{Electrochemical properties and chemical stability}

The impedance spectra were employed to understand the kinetics of ORR and electrocatalytic activity of the samples. The typical Nyquist plots of LCO-SDC, LMCO-SDC based cells from $500{ }^{\circ} \mathrm{C}$ to $600{ }^{\circ} \mathrm{C}$ in the air are shown in Fig. 5 (a) and (b), respectively. An equivalent circuit model of $L R_{\text {ohm }}\left(R_{1} Q_{1}\right)\left(R_{2} Q_{2}\right)$ presented as an inset in Fig. 5 (b) was used to fit the raw data by ZSimpWin software. $\mathrm{L}$ is caused by the inductance of the electrical equipment and electric wire and $R_{o h m}$ is mainly due to the ohmic resistance of the entire cell. In addition, $R_{1} / Q_{1}$ and $\mathrm{R}_{2} / \mathrm{Q}_{2}$ represents the high frequency and low-frequency resistance/capacitance, respectively. The high-frequency arc involves charge transfer during the migration and diffusion of oxygen ions from electrode/MIEC's interface, and the low-frequency arc is ascribed to the non-charge transfer process, such as oxygen surface exchange and oxygen gas diffusion through the electrode. ${ }^{33,34}$ The impedance of LCO-SDC and LMCO-SDC are 5.1, 2.4 and $0.85 \Omega \mathrm{cm}^{2}$ and 2.6, 1.03 and $0.5 \Omega \mathrm{cm}^{2}$ at 500,550 and $600{ }^{\circ} \mathrm{C}$, respectively. Both cell resistances decrease noticeably with increasing temperature, indicative of thermal activation behaviour of the electrode reaction process. Particularly, the lower charge transfer resistance of LMCO-SDC based cell is attributed to the replacement of $\mathrm{Co}^{3+}$ ions by lower valence $\mathrm{Mg}^{2+}$ ions that through charge compensation leads to the generation of $\mathrm{Co}^{4+}$ (holes) ions $\left(2 \mathrm{Co}^{3+} \rightarrow \mathrm{Co}^{4+}+\mathrm{Mg}^{2+}\right)$, thus enhancing the effective carrier concentrations whilst simultaneously reducing the area specific resistance (ASR) of Mg-doped $\mathrm{LiCoO}_{2}$.

The electrical properties of LCO-SDC and LMCO-SDC composite fuel cells were studied based on EIS. From the EIS, the total electrical conductivity was calculated according to:

$$
\sigma_{t}=\frac{L}{R_{\text {ohm }} \times A}
$$

Where $\mathrm{L}$ denotes the thickness, $\mathrm{A}$ is the effective area of the fuel cell and $\mathrm{R}_{\mathrm{ohm}}$ is ascribed to the ohmic resistance that was contributed by both ions and electrons. Meanwhile, the ionic 
conductivity $\left(\sigma_{i}\right)$ of both LCO-SDC and LMCO-SDC composite cells can be estimated from the slope of I-V curves (Fig. 7) according to:

$$
\sigma_{i}=\frac{L}{R_{A S R} \times A}=\frac{L \times i}{V_{\text {ohm }} \times A}
$$

Consequently, the electronic conductivity $\left(\sigma_{e}\right)$ can be obtained from the $\sigma_{i}$, according to. $\sigma_{e}=\sigma_{t}-\sigma_{i}$ At different temperature, the obtained conductivity $\left(\sigma_{t}, \sigma_{e}\right.$ and $\left.\sigma_{i}\right)$ values are shown in Table. 1

The LCO-SDC and LMCO-SDC composite fuel cell conductivity results under different atmospheres at different temperatures are plotted in Fig. 6. The ionic and electronic conductivity of LMCO-SDC was gradually increased compared to LCO-SDC with temperature, indicating the conducting behaviour of the semiconductor composite fuel cell. The lower $\sigma_{e}$ and $\sigma_{i}$ conductivities of LCO-SDC composite cell may originate from a poor LCO $\left(0.05 \mathrm{~S} / \mathrm{cm}\right.$ at $\left.600{ }^{\circ} \mathrm{C}\right)$ configuration that provides insufficient reaction cites leading to the triple phase boundary (TPB) for the ORR being only limited to the planner interface between electrode and composite LCO-SDC; meanwhile, the humidified conditions occur at intermediate temperature range resulting in high resistance of the composite cell. When the $\mathrm{Mg}$ was a substitute in LCO sites $\left(0.08 \mathrm{~S} / \mathrm{cm}\right.$ at $\left.600{ }^{\circ} \mathrm{C}\right)$, the grain size was reduced and expected to improve the triple-conducting kinetics involving charges such as protonic, oxygen ionic and electronic $\left(\mathrm{H}^{+} / \mathrm{O}^{2-} / \mathrm{e}^{-}\right)$at the LMCO-SDC interface. This is borne out and supports the FE-SEM results. From Fig. 6, we observed the LMCO-SDC composite reveals the $\sigma_{e}$ and $\sigma_{i}$ are almost balanced when compare to LCO-SDC composite cell, resulting in lower electrode polarization and enhancing the fuel cell performance of LMCO-SDC composites. ${ }^{35}$

Voltage and power density as a function of current density of the Ni-NCAL/SDC/NCAL$\mathrm{Ni}$ (supporting information Figure S3,), Ni-NCAL/LCO-SDC/Ni-NCAL and NiNCAL/LMCO-SDC/Ni-NCAL composite cells are tested at $500-600{ }^{\circ} \mathrm{C}$ by using hydrogen as fuel and ambient air as oxidant, and the results are shown in Fig 7 (a) and (b), respectively. The peak power densities are $0.5,0.4$ and $0.17 \mathrm{~W} / \mathrm{cm}^{2}$ and open circuit voltages (OCVs) are $0.89,0.85$ and $0.96 \mathrm{~V}$ respectively at 600,550 and $500{ }^{\circ} \mathrm{C}$ for the cell with LCO-SDC as a composite material, while the corresponding values are $0.7,0.54$ and $0.4 \mathrm{~W} / \mathrm{cm}^{2}$ and $1.02,0.89$ and $0.92 \mathrm{~V}$ for the cell with LMCO-SDC as a composite material. The enhanced electrochemical performance of LMCO composite is ascribed to $\mathrm{Mg}^{2+}$ incorporated into the $\mathrm{LiCoO}_{2}$ layer, and the $\mathrm{Mg}^{2+}$ served as pillars to prevent $\mathrm{CoO}_{2}$ intraslab from collapse and stabilized the layered structure of $\mathrm{LiCoO}_{2}$ in its delithiated $\left(\mathrm{Li}^{+} / \mathrm{H}^{+}\right)$state at high potentials (Fig. 
2). Moreover, it is known that well-developed lithiated layered structures contain the triple charge $\left(\mathrm{H}^{+} / \mathrm{O}^{2-} / \mathrm{e}^{-}\right)$conducting properties. ${ }^{3}$ Therefore, we can conclude that the decent electrochemical performance of the assembled cell should be attributed to its sufficient electrical conductivity and high electrocatalytic for fuel oxidation and oxygen reduction. However, it should be noted that our triple conducting LCO-SDC and LMCO-SDC used in our fuel cell devices acted as the electrolyte. According to conventional SOFC science, an electronically conductive material cannot be used for electrolyte, as this will curtail the device's OCV and power output to a serious degree due to the electronic short circuiting problem. However, in stark contrast, our results demonstrated the opposite, as both OCVs and power outputs have shown excellent performance. This is constitutive of the so-called semiconductorionic membrane fuel cell technologies. Based on the above studies, the electronic (hole) conduction in mixed p-type semiconductor (LCO or LMCO) and ionic conductor (SDC) may be blocked by a Schottky junction, thus preventing the short circuit problem. In addition, as per our previous reports, the built in field of the Schottky junction can promote the ions $\left(\mathrm{H}^{+}\right.$or $\mathrm{O}_{2}$ ) transport, further enhancing the current and power outputs in fuel cell conditions. Thus, such devices can deliver excellent performances. ${ }^{17,24,36}$

The optical bandgap energy $\left(\mathrm{E}_{\mathrm{g}}\right)$ of the LCO and LMCO samples were further determined in the wavelength range 300 to $2500 \mathrm{~nm}$ by the data of the reflectance versus wavelength plot shown in supporting information Figure $\mathrm{S}_{4}$. The exact energy at which it reflects is estimated using the Kubelka-Munk (K-M) function described as.

$$
F(R)=\frac{(1-R)^{2}}{2 R}
$$

Where $F(R)$ is the K-M function, $R$ is the reflectance. Fig 8 (a) shows the plot between $[F(R)$ $h v]^{2}$ vs hv of the LCO and LMCO samples. As the results presented show, the $\mathrm{E}_{\mathrm{g}}$ was reduced from 2.65 to $2.24 \mathrm{eV}$, when $\mathrm{Mg}^{2+}$ ion doped into $\mathrm{LiCoO}_{2}$ sites, resulting in increases to both the Co-O bond length and the concentration of electronic holes. In addition, the narrow band gap of LMCO was clarified by XPS. The XPS valence band maximum (VBM) position for $\mathrm{LCO}$ and $\mathrm{LMCO}$ are 1.64 and $1.80 \mathrm{eV}$, respectively, with respect to the Fermi edge at $0 \mathrm{eV}$ binding energy shown in Fig 8 (b). The VBM shifted towards higher BE of the energy axis for LMCO with respect to the LCO, suggesting that for LMCO, the VBM shifted downwards with respect to the LCO. Meanwhile, the conduction band also shift downward with respect to the energy levels of the LCO, and the position of the Fermi level lies close to the valence band, a complete band energy as presented in Fig 8 (c). The narrowing band gap would be favourable to the improvement of the electronic (hole) conductivity of the semiconducting material. ${ }^{37}$ 
The durability of LT-SOFCs is also a key impediment for practical applications. We investigated the durability of the Ni-NCAL/LCO-SDC/Ni-NCAL and Ni-NCAL/LMCOSDC/Ni-NCAL cells operated at a constant current density of $200 \mathrm{~mA} / \mathrm{cm}^{2}$ at $600{ }^{\circ} \mathrm{C}$, and the voltage recorded as a function of time (h,hours), as shown in Fig 9 (a). The LCO-SDC and LMCO-SDC composite cells are operated under the resulting potential which are 0.18 and 0.79 $\mathrm{V}$ respectively, shown in Fig 9 (a). The superior performance of LMCO-SDC composite cell operates with stability for $10 \mathrm{~h}$ without significant degradation. In contrast, LCO-SDC composite cell fluctuated after $2 \mathrm{~h}$, with the limitation of LCO-SDC composite mainly due to the redistribution of molecular orbitals between the Co and oxygen during the electro analytical process, and this is explained by using band structure (Energy vs Density of states) shown in Fig. 9 (b-d). The layered rock-salt $\mathrm{LiCoO}_{2}$ consisting of $\mathrm{Co}-3 \mathrm{~d}$ bands are divided by three Co$t_{2 g}$ (valence band) and two Co-e $\mathrm{e}_{\mathrm{g}}$ (Conduction band) bands. ${ }^{38}$, Fig. 9 (c) shows the $\mathrm{LiCoO}_{2}$ band structure before the fuel cell condition. In fuel cell condition, the $\mathrm{Li}^{+} / \mathrm{H}^{+}$can be extracted from the $\mathrm{LiCoO}_{2}$, the $\mathrm{Co}^{3+}$ ions are oxidized to $\mathrm{Co}^{4+}$, which is accompanied by a removal of electrons from the Co: $t_{2 g}$ band. Meanwhile, the Co: $t_{2 g}$ band overlaps on the top of the $\mathrm{O}^{2-:} 2 \mathrm{p}$ band shown in Fig. 9 (c). It leads to oxidation of $\mathrm{O}^{2-}$ and oxygen loss from the lattice, which is a known reason for the degradation of the fuel cell durability. In contrast, the good durability with higher performance of LMCO-SDC cell could be attributed to the Mg doping on Co sites, as it maintains the Co: $t_{2 g}$ band level higher than that of the $\mathrm{O}^{2-:}: 2 \mathrm{p}$ band and it prevents the oxygen loss from the lattice, ${ }^{39,40}$ shown in Fig 9 (d).

On the other hand, energy band affects not only on electronic conductivity but also on the total electrical properties including ions. By doping excepting LCO energy band gap Eg reduced from $2.65 \mathrm{eV}$ to $2.24 \mathrm{eV}$, the total conductivities increased from $0.52 \mathrm{~S} / \mathrm{cm}$ to 1.36 $\mathrm{S} / \mathrm{cm}$; in addition, ionic conductivity which is deduced from the fuel cell $\mathrm{I}-\mathrm{V}$ curves, increased from $0.30 \mathrm{~S} / \mathrm{cm}$ up to $0.72 \mathrm{~S} / \mathrm{cm}$, respectively, at $600{ }^{\circ} \mathrm{C}$. It can be seen from Fig. 6 that the electrical conductivities obtained by EIS increase significantly in correspondence with $\mathrm{Mg}^{2+}$ prevent the $\mathrm{Co}^{4+}$ from overlap into the oxidation state and it does not hinder the $\mathrm{Li}^{+} / \mathrm{H}^{+}$ion diffusion because it has a similar ionic radii to $\mathrm{Li}^{+}\left(0.76 \mathrm{~A}^{\circ}\right)$ ions. The greater freedom for ionic mobility led to improvement of ionic conduction and mobility as well as commensurate increases in fuel cell device power output. Here, the Ni-NCAL/LMCO-SDC/Ni-NCAL composite cell is shown to be very promising in terms of its results, and its durability has been extended from $2 \mathrm{~h}$ (LCO) to $10 \mathrm{~h}$ (for LMCO). All these improvements are made by band effects on i) the material conductivities both for ionic (from $0.22 \mathrm{~S} / \mathrm{cm}$ to $0.35 \mathrm{~S} / \mathrm{cm}$ ) and electronic (from $0.142 \mathrm{~S} / \mathrm{cm}$ to $0.4 \mathrm{~S} / \mathrm{cm}$ ) and ii) the device power output from 0.5 to $0.7 \mathrm{w} / \mathrm{cm}^{2}$ with 
iii) polarization resistance from $0.85 \Omega \mathrm{cm}^{2}$ decreasing to $0.5 \Omega \mathrm{cm}^{2}$ and iv) durability enhanced from $2 \mathrm{~h}$ to $10 \mathrm{~h}$ as compared between the LCO and LMCO devices at $600{ }^{\circ} \mathrm{C}$, as shown in Fig 10. Even longer durability demands strong engineering efforts to be continued in ongoing research and development. The results have, at this far demonstrated conclusively and emphatically that semiconductor and band designs have made a new and effective approach to develop next-generation advanced LT-SOFCs.

\section{Conclusions}

We report on a new approach by design and change energy band structures to make great improvements on the layer structured LCO material properties and their fuel cell performances. The Mg-doped LCO is a hexagonal layered structure with an R3m space group of LCO. The doping made LMCO with a narrower band gap $(2.24 \mathrm{eV})$ than that of LCO $(2.65 \mathrm{eV})$ and produced a significant ionic conductivity enhancement from $0.22 \mathrm{~S} / \mathrm{cm}$ to $0.35 \mathrm{~S} / \mathrm{cm}$. Consequently, the LMCO-SDC device reveals low charge transfer resistance of $0.4 \Omega \mathrm{cm}^{2}$ and high power density $0.7 \mathrm{~W} / \mathrm{cm}^{2}$ with good stability at $600{ }^{\circ} \mathrm{C}$. The results have demonstrated that designing and changing the band structure can make great impact on material conductivity and the fuel cell device performance, exhibiting great potential and advances for new generation LT-SOFCs.

\section{Acknowledgements}

Financial support are from the National Natural Science Foundation of China (Grant 51772080, 51502084), the Swedish Research Council (VR, Contract No. 621-2011-4983) and the EC FP7 TriSOFC project (Contract No. 303454).

\section{References}

(1) Yunhui, G.; D. P., Xueyan, S.; Rajankumar L.-P.; Xinhua, L.; Xuan, Z.; Goodenough, J.-B.; Kevin, H. Stabilizing Nanostructured Solid Oxide Fuel Cell Cathode with Atomic Layer Deposition. Nano Lett. 2013, 13 (9), 4340-4345.

(2) Sihyuk, C.; S. Y., Jiyoun, K.; Seonhye, P.; Areum, J.; Sivaprakash, S.; Junyoung, K.; Jeeyoung, S.; Hu, Y.-J.; YongMan, C.; Guntae, K.; Meilin, L.; Highly Efficient and Robust Cathode Materials for Low-Temperature Solid Oxide Fuel Cells: $\operatorname{PrBa}_{0.5} \mathrm{Sr}_{0.5} \mathrm{CO}_{2-\mathrm{x}} \mathrm{Fe}_{\mathrm{x}} \mathrm{O}_{5+\delta}$. Scientific Reports 2013; Vol. 3. 
(3) Liangdong, F.; P.-C. S., Layer-Structured $\mathrm{LiNi}_{0.8} \mathrm{Co}_{0.2} \mathrm{O}_{2}$ : A New Triple $\left(\mathrm{H}^{+} / \mathrm{O}^{2-} / \mathrm{e}^{-}\right)$Conducting Cathode for Low Temperature Proton Conducting Solid Oxide Fuel Cells. J. Power Sources 2016, 306, 369-377.

(4) Liming, D.;, L. W., Dong, D.; Shihua, Z.; Xifeng, D.; Guoliang, Y.; Promotion on Electrochemical Performance of a Cation Deficient $\mathrm{SrCO}_{0.7} \mathrm{Nb}_{0.1} \mathrm{Fe}_{0.2} \mathrm{O}_{3-\delta}$ Perovskite Cathode for Intermediate-Temperature Solid Oxide Fuel Cells. J. Power Sources 2017, 354, 26-33.

(5) Bin, L.; X. C., Yonglai, D.; Samuel, S.-M.; Mojie, C.; A High-Performance, Nanostructured $\mathrm{Ba}_{0.5} \mathrm{Sr}_{0.5} \mathrm{Co}_{0.8} \mathrm{Fe}_{0.2} \mathrm{O}_{3-\delta}$ Cathode for Solid-Oxide Fuel Cells. Adv. Energy Mater. 2011, 1, 343346.

(6) Changrong, X.; W. R., Fanglin, C.; Meilin, L.; $\mathrm{Sm}_{0.5} \mathrm{Sr}_{0.5} \mathrm{CoO}_{3}$ Cathodes for Low-Temperature Sofcs. Solid State Ionics. 2002, 149, 11-19.

(7) Baoyuan, W.; Yixiao, C.; Chen, X.; Sik, K. -J.; Yanyan, L.; Wenjing, D.; Hao, W.; Muhammad, A.; Junjiao, L.; Rizwan, R.; Bin, Z.; Semiconductor-Ionic Membrane of LaSrCoFe-OxideDoped Ceria Solid Oxide Fuel Cells. Electrochimica Acta 2017, 248, 496-504.

(8) He, W.; Wu, X.; Yang, G.; Shi, H.; Dong, F.; Ni, M., $\mathrm{BaCO}_{0.7} \mathrm{Fe}_{0.22} \mathrm{Y}_{0.08} \mathrm{O}_{3-\delta}$ as an Active Oxygen Reduction Electrocatalyst for Low-Temperature Solid Oxide Fuel Cells Below $600{ }^{\circ} \mathrm{C}$. ACS Energy Letters 2017, 2, 301-305.

(9) Chuancheng, D.; M. S., Jianhua, T.; Sandrine, R.; Meng, S.; Ali, A.; Stefan, N.; Ryan, O'. Readily Processed Protonic Ceramic Fuel Cells with High Performance at Low Temperatures. Science 2015, 349, 1321-1326.

(10) Rong, L.; Shanwen, T. Novel Proton Conductors in the Layered Oxide Material $\mathrm{Li}_{\mathrm{x}} \mathrm{Al}_{0.5} \mathrm{Co}_{0.5} \mathrm{O}_{2}$. Adv. Energy Mater. 2014, 4, (1 of 6) 1301683.

(11) Litty, S.; R. S. Jayashree.; Gopalakrishnan, j. Probing the mobility of lithium in LISICON: $\mathrm{Li}^{+} / \mathrm{H}^{+}$exchange studies in $\mathrm{Li}_{2} \mathrm{ZnGeO}_{4}$ and $\mathrm{Li}_{2+2 x} \mathrm{Zn}_{1-x} \mathrm{GeO}_{4 . .} J$. Mater. Chem. 2003, 13, 14001405.

(12) Jeevan Kumar, P.; Jayanth Babu, K.; Hussain, O.-M. Enhanced electrochemical properties of as grown $\mathrm{LiCoO}_{2}$ film cathodes: Influence of silicon substrate surface texturing. Material Chemistry and Physics 2014, 143, 536-544.

(13) Sivajee Ganesh, K.; Purusottam Reddy, B.; Jeevan Kumar, P.; Jayanth babu, K.; Rosaiah, P.; Hussain, O.-M. Microstructural and electrochemical properties of $\mathrm{LiTi}_{\mathrm{y}} \mathrm{CO}_{1-\mathrm{y}} \mathrm{O}_{2}$ film cathodes prepared by RF sputtering. J Solid State Electrochem. 2015, 19, 3621-3627.

(14) Kim, S.-H.; C.S. Kim. Improving the rate performance of $\mathrm{LiCoO}_{2}$ by $\mathrm{Zr}$ doping, J. Electroceram. 2009, 23, 254-257. 
(15) Luo, D.; Li, G.; Yu, C.; Yang, L.; Zheng, J.; Guan, X.; Li, L. Low-concentration donor-doped $\mathrm{LiCoO}_{2}$ as a high performance cathode material for Li-ion batteries to operate between 10.4 and $45.4^{\circ}$ C. J. Mater. Chem. 2012, 22, 22233-22241.

(16) Levasseur, S.; Menetrier, M.; Delmas, C. On the dual effect of $\mathrm{Mg}$ doping in $\mathrm{LiCoO}_{2}$ and $\mathrm{Li}_{1+\delta} \mathrm{CoO}_{2}$ : structural, electronic properties, and ${ }^{7} \mathrm{Li}$ MAS NMR studies, Chem. Mater. 2002, 14, 3584-3590.

(17) Bin Zhu.; Liangdong, F.; Hui, D.; Yunjune, H.; Muhammad, A.; Wenjing, D.; Azra, Y.; Naveed, K.-J. LiNiFe-based layered structure oxide and composite for advanced single layer fuel cells. J. Power Sources 2016, 316, 37-43.

(18) Limin, Z.; Jing, Y.; Juan, L. A novel composite cathode for intermediate temperature solid oxide fuel cell. J. Power Sources 2014, 269, 723-726.

(19) Tukamoto, H.; A. R. West, Electronic Conductivity of $\mathrm{LiCoO}_{2}$ and Its Enhancement by Magnesium Doping. J. Electrochem. Soc. 1997, 144, 3164-3168.

(20) Jeevan-Kumar, P.; Jayanth-Babu, K.; Hussain, O.-M.; Julien, C.-M. RF Sputtered LiCoO ${ }_{2}$ thick films: microstructure and electrochemical performance as cathodes in aqueous and nonaqueous microbatteries. Ionics 2013, 19, 421-428.

(21) Sivajee-Ganesh, K.; Purusottam-Reddy, B.; Hussain, O.M.; Mauger, A.; Julien, C.-M. Influence of $\mathrm{Ti}$ and $\mathrm{Zr}$ dopants on the electrochemical performance of $\mathrm{LiCoO}_{2}$ film cathodes prepared by rf-magnetron sputtering. Materials Science and Engineering B 2016, 209, 3036.

(22) Zhou, Y.; Guan, X.; Zhou, H.; Ramadoss, K.; Adam, S.; Liu, H.; Lee, S.; Shil, J.; Tsuchiya, M.; Fong, D.-D.; Ramanathan, S. Strongly correlated perovskite fuel cells. Nature 2016, 534, 231-234.

(23) Bin Zhu, Wang, B.; Wang, Y.; Razad, R.; Tane, W.; Kimf, J.-S.; van Aken, P.-A.; Lund, P.; Charge separation and transport in $\mathrm{La}_{0.6} \mathrm{Sr}_{0.4} \mathrm{Co}_{0.2} \mathrm{Fe}_{0.8} \mathrm{O}_{3-\delta}$ and ion-doping ceria heterostructure material for new generation fuel cell. Nano Energy 2017 37, 195-202.

(24) Bin Zhu, Peter, D.-L.; Rizwan, R.; Ying, M.; Liangdong, F.; Muhammad, A.; Janne, P.; Yunjun, H.; Yufeng, Z.; Wenyi, T.; Qiu-An, H.; Jun, Z.; Hao, W. Schottky Junction Effect on High Performance Fuel Cells Based on Nanocomposite Materials. Adv. Energy Mater. 2015, 1401895.

(25) Zhu, B.; Yun, S.; Lund, P.-D. Semiconductor-ionic materials could play an important role in advanced fuel-to-electricity conversion. Int J Energy Res. 2018, 1-3. DOI: 10.1002/er.4105

(26) Ho-Jin, K.; Yeon, U.-J.; Joon-Hyung, L.; Jeong-Joo, K. Crystal structures, electrical conductivities and electrochemical properties of $\mathrm{LiCo}_{1-\mathrm{x}} \mathrm{Mg}_{\mathrm{x}} \mathrm{O}_{2}(0 \leq \mathrm{x} \leq 0.11)$. J. Power Sources 2006, 159, 233-236. 
(27) Gopukumar, S.; Jeong, Y.; Bum Kim, K. Synthesis and electrochemical performance of tetravalent doped $\mathrm{LiCoO}_{2}$ in lithium rechargeable cells. Solid State lonics 2003, 159, $223-$ 232.

(28) Cheng, J.-H.; Pan, C.;-J.; Nithya, C.; Thirunakaran, R.; Gopukumar, S.; Chen, C.-H.; Lee, J.-F.; Chen, J.-M.; Sivashanmugam, A.; Hwang, B.-J. Effect of Mg doping on the local structure of $\mathrm{LiMg}_{\mathrm{y}} \mathrm{Co}_{1-\mathrm{y}} \mathrm{O}_{2}$ cathode material investigated by $\mathrm{X}$-ray absorption spectroscopy. J. Power sources 2014, 252, 292-297.

(29) Zaheena, C.-N.; Nithya, C.; Thirunakaran, R.; Sivashanmugam, A.; Gopukumar, S. Microwave assisted synthesis and electrochemical behaviour of $\mathrm{LiMg}_{0.1} \mathrm{Co}_{0.9} \mathrm{O}_{2}$ for lithium rechargeable batteries. Electrochimica Acta 2009, 54, 2877-2882.

(30) Daheron, L.; Martinez, H.; Dedryvere, R.; Baraille, I.; Menetrier, M.; Denage, C.; Delmas, C.; Gonbeau, D. Surface properties of $\mathrm{LiCoO}_{2}$ investigated by XPS analyses and theoretical calculations. J Phys. Chem. C. 2009, 113, 5843-5852.

(31) Liang, D.D.; Xiang, H.-F.; Liang, X.; Cheng, S.; Chen, C.-H. Spinel $\mathrm{MgAl}_{2} \mathrm{O}_{4}$ modification on $\mathrm{LiCoO}_{2}$ cathode materials with the combined advantages of $\mathrm{MgO}$ and $\mathrm{Al}_{2} \mathrm{O}_{3}$ modifications for high-voltage lithiumion batteries. RSC Adv. 2017, 7, 6809-6817.

(32) Yanyan, L.; Liangdong, F.; Yixiao, C.; Wei, Z.; Baoyuan, W.; Bin, Z. Superionic Conductivity of $\mathrm{Sm}^{3+}, \mathrm{Pr}^{3+}$, and $\mathrm{Nd}^{3+}$ Triple-Doped Ceria through Bulk and Surface Two-Step Doping Approach. ACS Appl. Mater. Interfaces 2017, 9, 23614-23623.

(33) Zheng, Q.; Chen, X.; Yixiao, C.; Muhammad, A.; Hao, W.; Jinli, Q.; Bin, Z. Electrochemical and electrical properties of doped $\mathrm{CeO}_{2}-\mathrm{ZnO}$ composite for low-temperature solid oxide fuel cell applications. J. Power Sources 2018, 392, 33-40.

(34) Zhihong, D.; Hailei, Z.; Yongna, S.; Lu, W.; Mengya, F.; Konrad, S.; Kun, Z. Evaluation of $\mathrm{La}_{0.3} \mathrm{Sr}_{0.7} \mathrm{Ti}_{1-\mathrm{x}} \mathrm{CO}_{\mathrm{x}} \mathrm{O}_{3}$ as a potential cathode material for solid oxide fuel cells. J. Mater. Chem. A. 2014,2,10290-10299.

(35) Chen, X.; Yixiao, C.; Baoyuan, W.; Muhammad, A.; Wei, Z.; Aslan, S.; Bin, Z. Strategy towards cost-effective low-temperature solid oxide fuel cells: A mixed-conductive membrane comprised of natural minerals and perovskite oxide. J. Power Sources 2017, 342, 779-786.

(36) Bin Zhu, Peter, L.; Rizwan, R.; Janne, P.; Qiu-An, H.; Liangdong, F.; Manish, S. A new energy conversion technology based on nano-redox and nano-device processes. Nano Energy 2013, 2, 1179-1185.

(37) Arshad, M.-S.; Trafela, S.; Rozman, K.-Z.; Kovac, J.; Djinovic, P.; Pintar, A. Determination of Schottky barrier height and enhanced photoelectron generation in novel plasmonic immobilized multisegmented $\left(\mathrm{Au} / \mathrm{TiO}_{2}\right)$ nanorod arrays (NRAs) suitable for solar energy conversion applications. J. Mater. Chem. C. 2017, 5, 10509-10516. 
(38) Kushida, K.; Kuriyama, K. Optical absorption related to Co-3d bands in sol-gel grown $\mathrm{LiCoO}_{2}$. Solid State Communications 2001, 118, 615-618.

(39) Julien, C,-M.; Mauger, A.; Zaghib, K.; Groult, H. Comparative Issues of Cathode Materials for Li-Ion Batteries. Inorganics 2014, 2, 132-154.

(40) Chebiam, R,-V.; Kannan, A,-M.; Prado, F.; Manthiram, A. Comparison of the chemical stability of the high energy density cathodes of lithium ion batteries. Electrochemistry communications 2001, 3, 624-627. 


\section{Figures:}

Fig. 1 XRD patterns of the as-prepared (a) $\mathrm{SDC}$ (b) $\mathrm{LiCoO}_{2}$ (c) $\mathrm{LiMg}_{0.1} \mathrm{Co}_{0.9} \mathrm{O}_{2}$ and mixed ionic and semiconducting electrodes are (d) LCO-SDC and (e) LMCO-SDC.

Fig. 2 The layered crystal structure of $\mathrm{Mg}$-doped $\mathrm{LiCoO}_{2}$.

Fig. 3 FE-SEM micrographs of (a) $\mathrm{LiCoO}_{2}$ (b) $\mathrm{LiMg}_{0.1} \mathrm{Co}_{0.9} \mathrm{O}_{2}$ (c) SDC (d) LCO-SDC (e) LMCO-SDC (f) cross sectional image of Ni-NCAL/LMCO-SDC/Ni-NCAL and TEM of (g) LCO-SDC (h) LMCO-SDC composite powders and (i) HR-TEM of LMCO-SDC composite with phases.

Fig. 4 The XPS spectra of LMCO-SDC composite cell core-level emissions. (a) Li (1s), (b) Co (2p), (c) Mg (1s), (d) Ce (3d), (e) Sm (3d) and (f) O (1s).

Fig. 5 Nyquist curves of (a) Ni-NCAL/LCO-SDC/Ni-NCAL and (b) Ni-NCAL/LMCOSDC/Ni-NCAL fuel cell with equivalent circuit model shown in inset Fig 5 (b).

Fig. 6 Temperature dependence of the ionic and electronic conductivities of LCO-SDC and LMCO-SDC composite cells.

Fig.7 Typical I-V and I-P curves of (a) Ni-NCAL/LCO-SDC/ Ni-NCAL and (b) Ni-NCAL/ LMCO-SDC/ Ni-NCAL fuel cells measured at temperature between $500{ }^{\circ} \mathrm{C}$ and $600{ }^{\circ} \mathrm{C}$.

Fig. 8 Durability of (a) LCO-SDC and (b) LMCO-SDC composite cells tested under a constant current density of $200 \mathrm{~mA} / \mathrm{cm}^{2}$ at $600{ }^{\circ} \mathrm{C}$. And the Energy vs Density of states for (c) $\mathrm{LiCoO}_{2}$ and the variations of energy bands during the durability test on Fuel cell conditions for (d) $\mathrm{LiCoO}_{2}$ and (e) $\mathrm{LiMg}_{0.1} \mathrm{Co}_{0.9} \mathrm{O}_{2}$.

Fig. 9 (a) The optical band gap spectra of the LCO and LMCO samples. And (b) XPS valence band maximum (VBM) of LCO and LMCO, the Fermi energy scale is zero at the VBM and (c) Schematic band energy alignment of LCO and LMCO.

Fig. 10 Schematic diagram of Fuel cell performance, such as Power density, Ionic conductivity and Durability with energy band alignment, Here A: Ni-NCAL/LCO-SDC/Ni-NCAL and B: Ni-NCAL/LMCO-SDC/Ni-NCAL 
Fig. 1

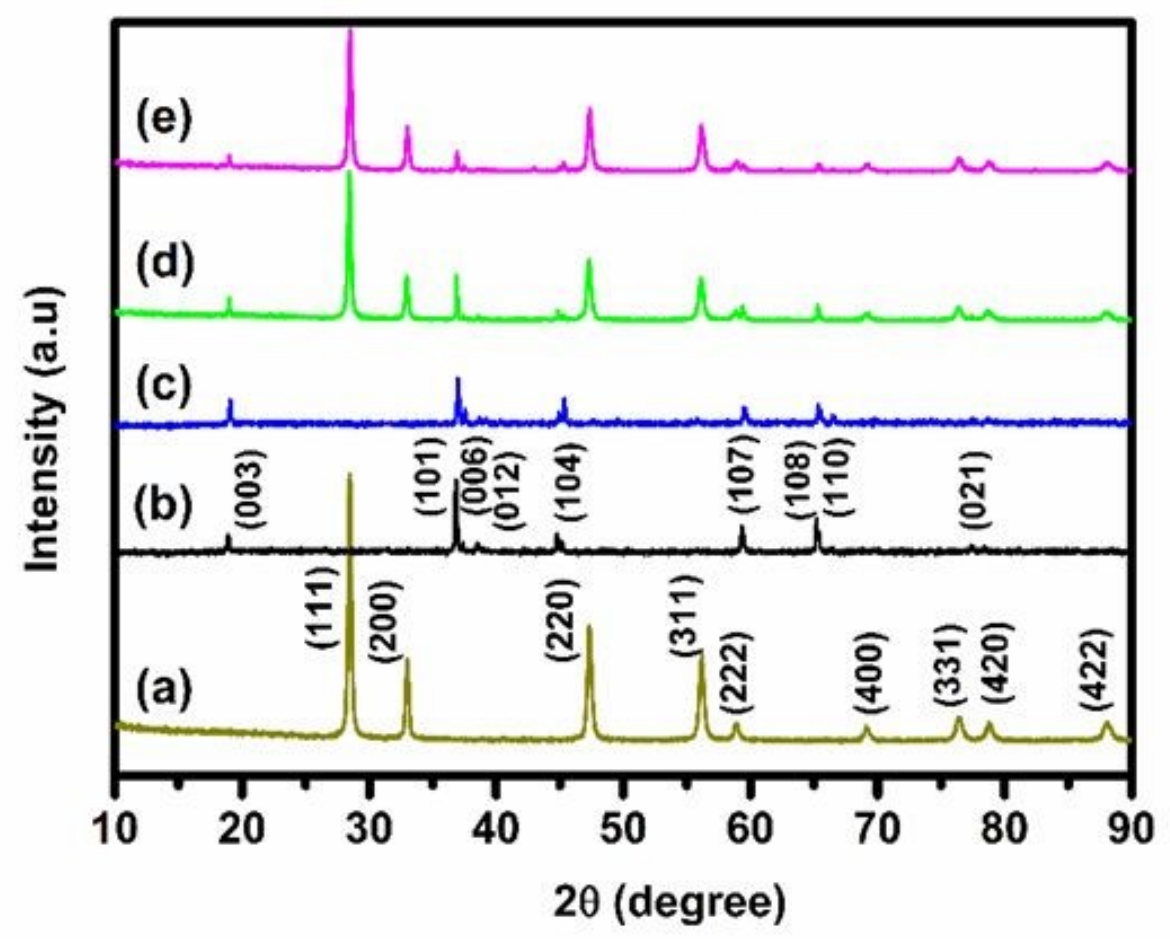

Fig. 2

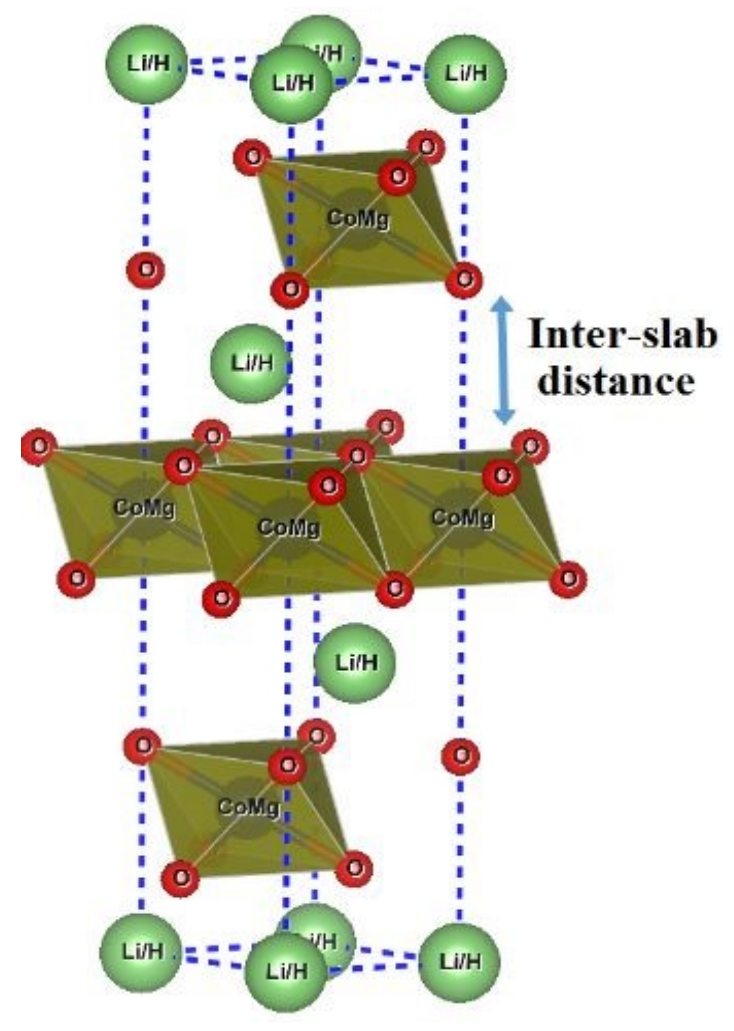


Fig. 3
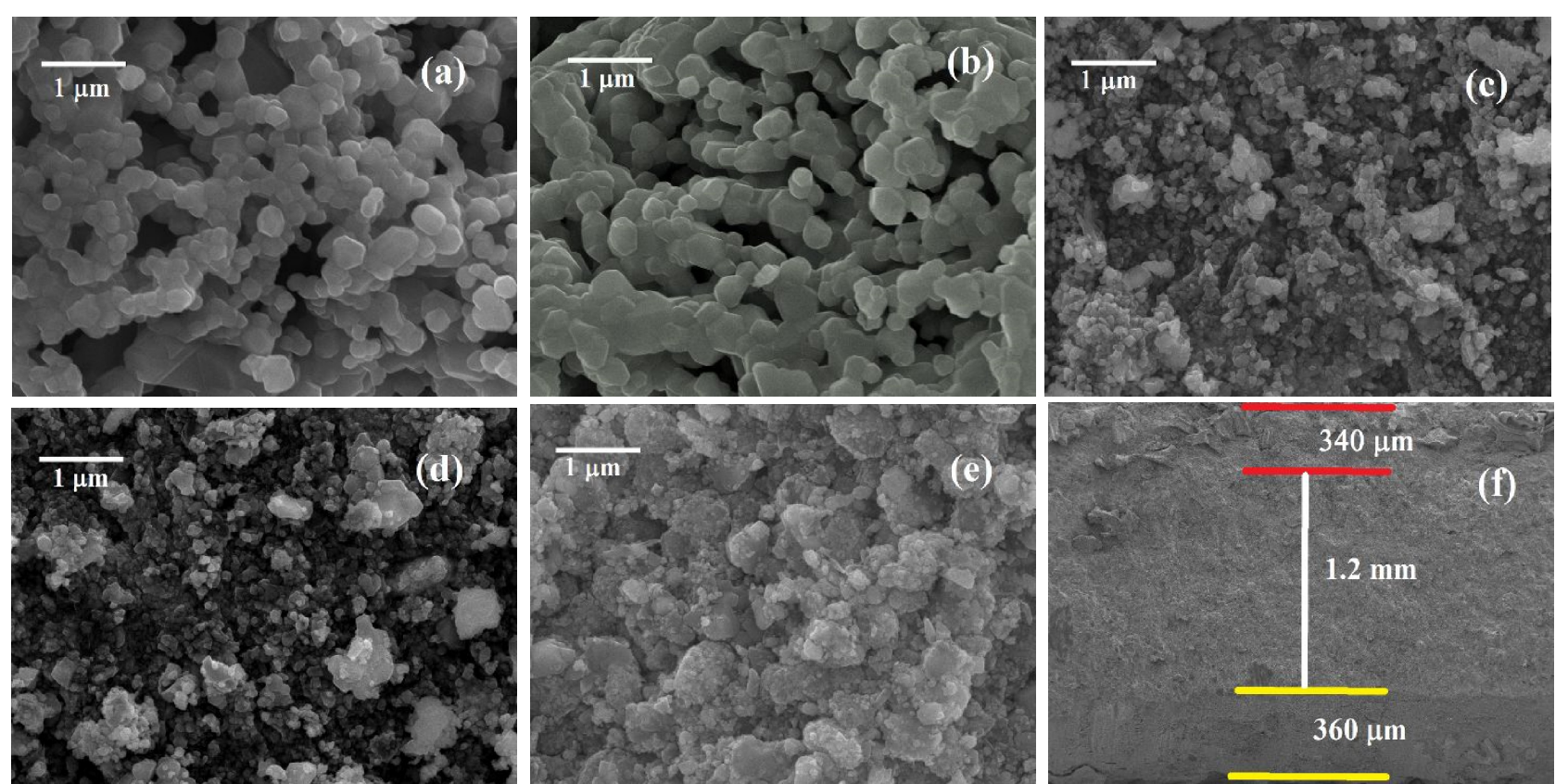

19

20

21

22

23

24

25

26

27

28

29

30

31

32

33

34

35

36

37

38

39

40

41

42

43

44

45

46

47

48

49

50

51

52

53

54

55

56

57

58

59
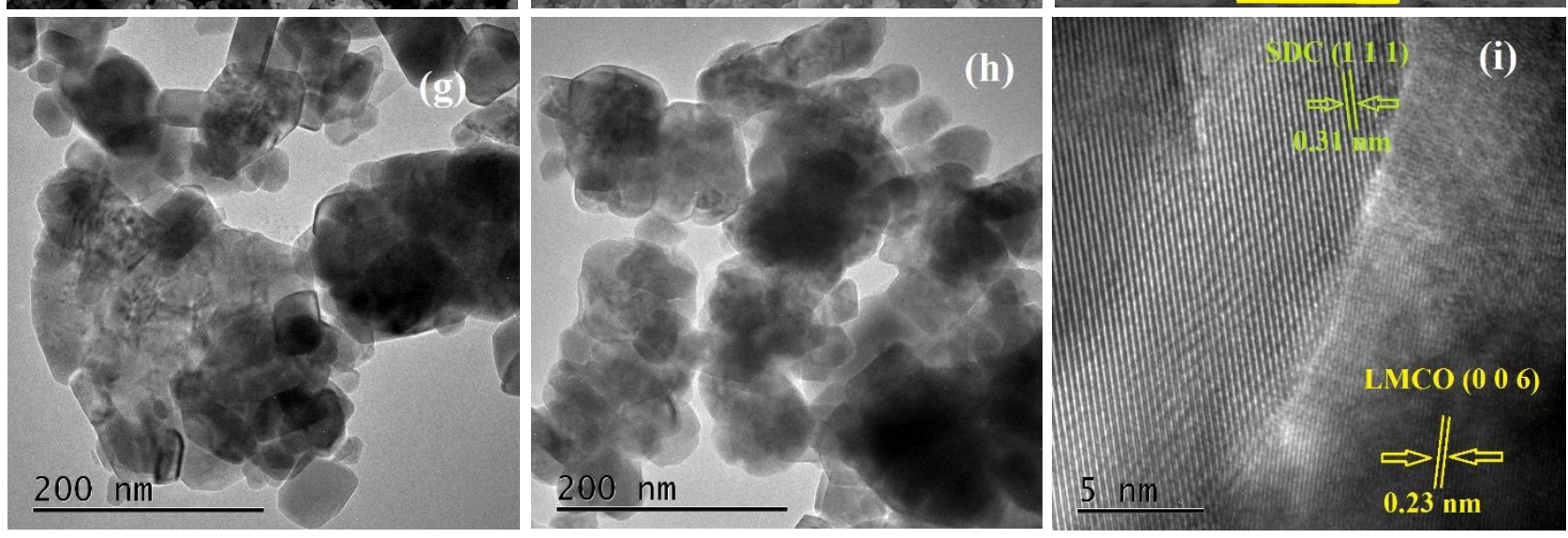

60 
Fig. 4
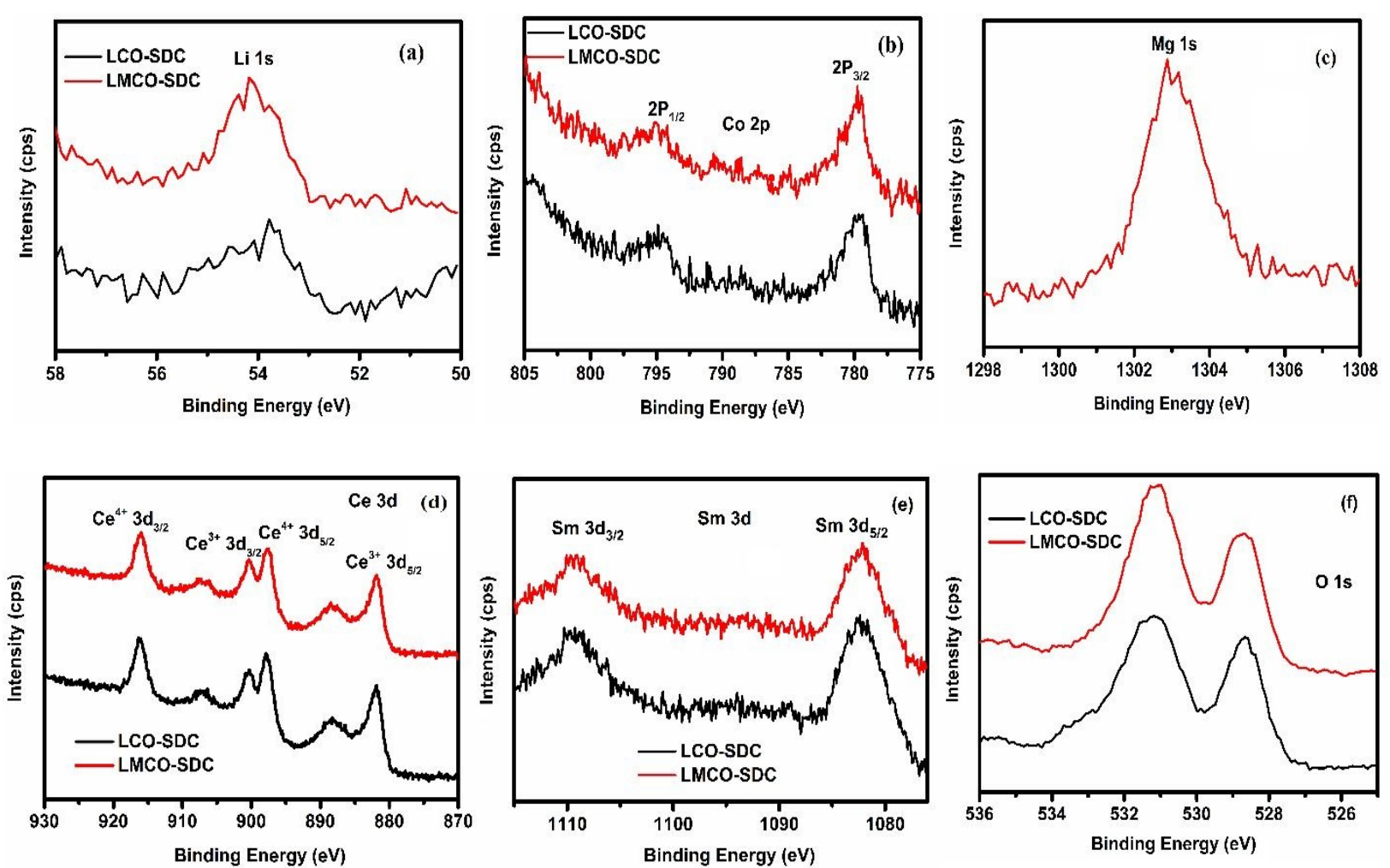

Fig. 5
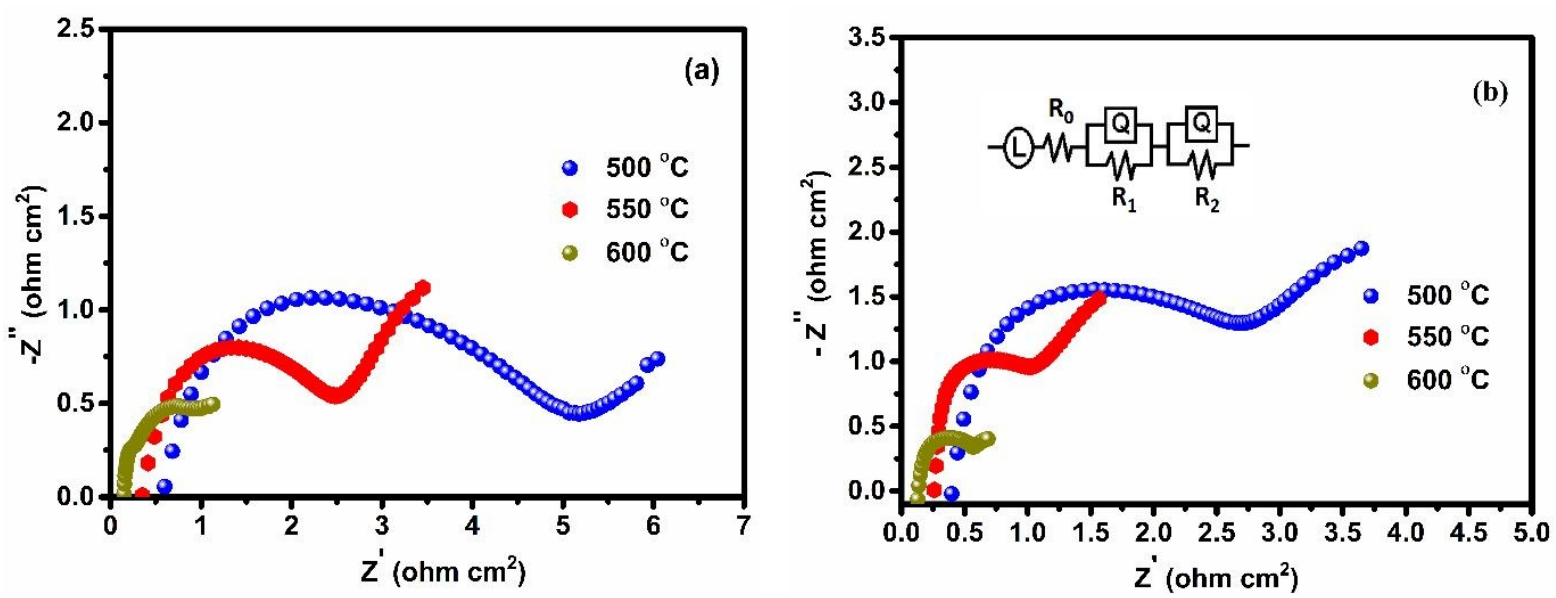
Fig. 6

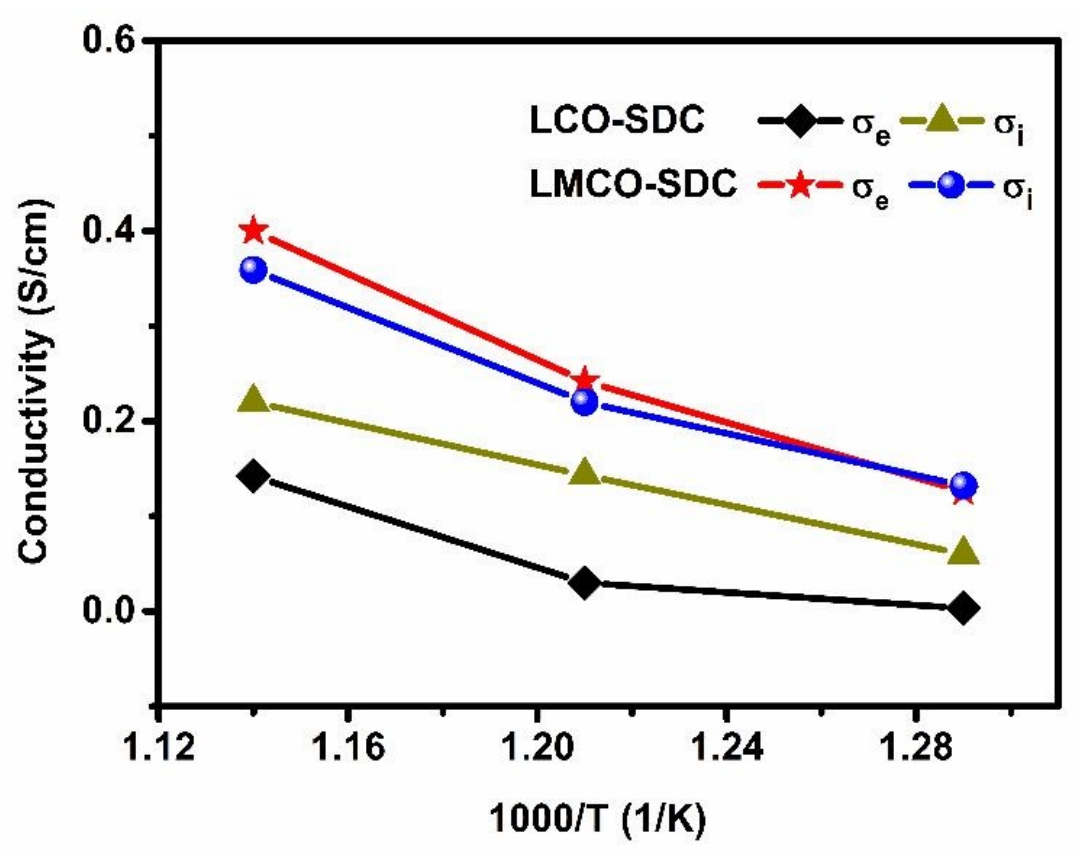

Fig. 7
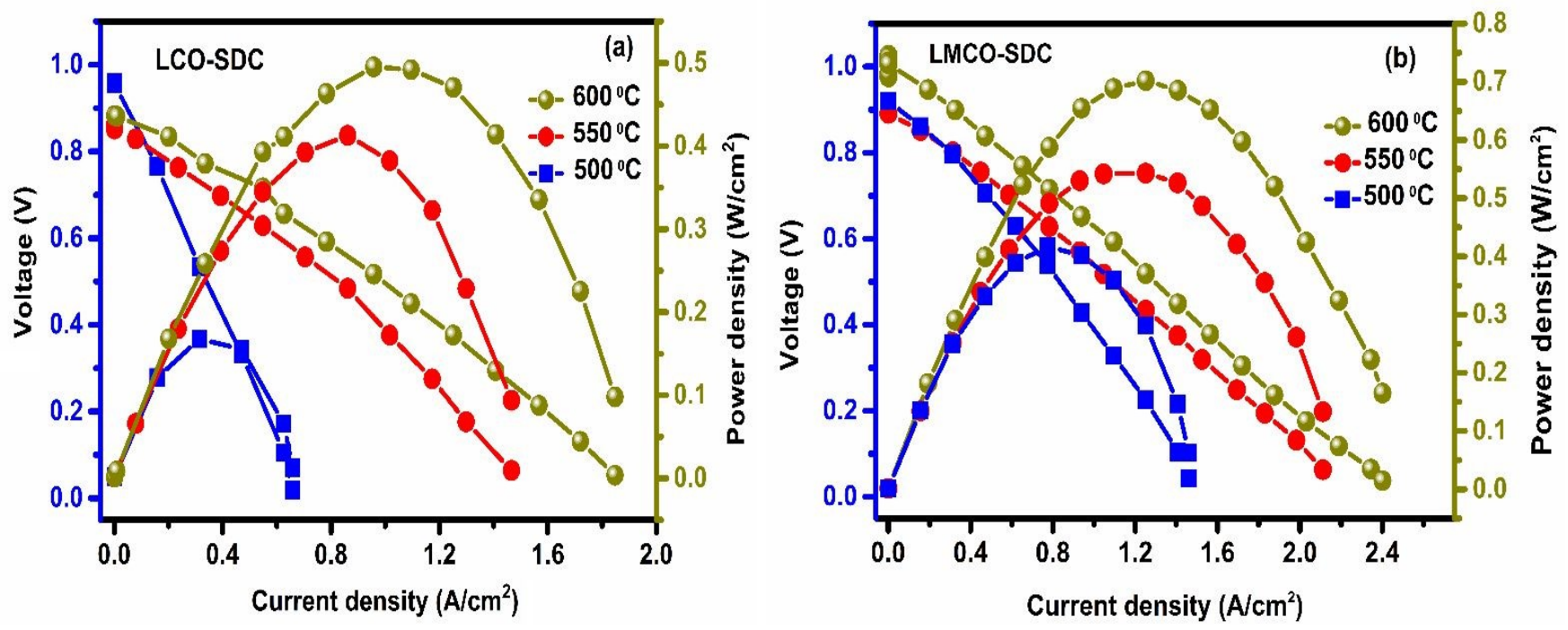
Fig. 8
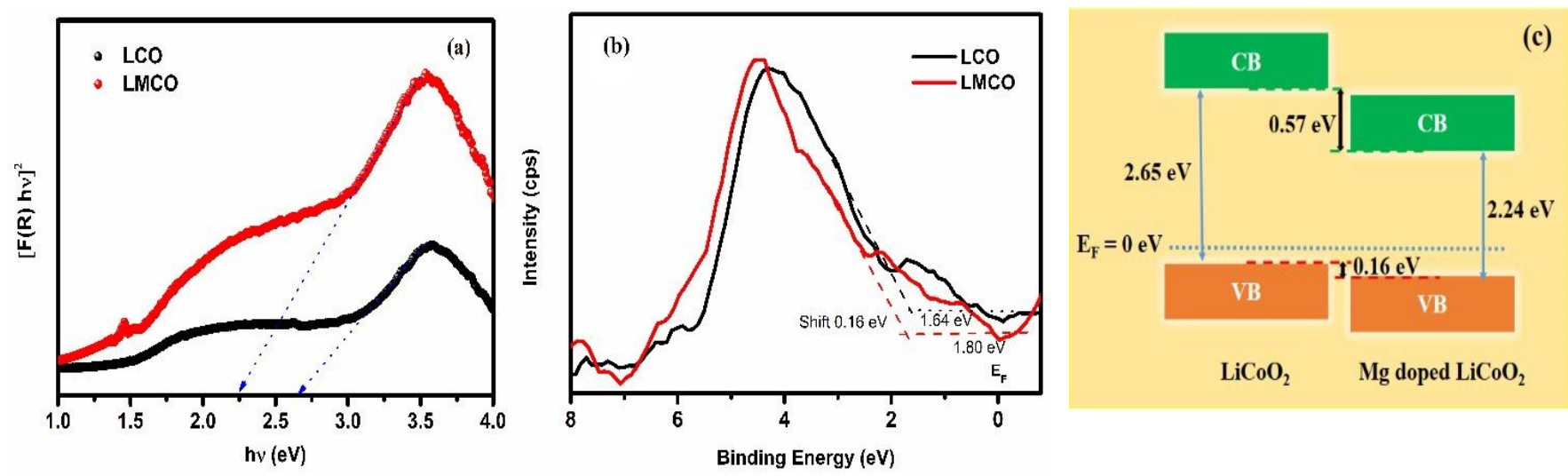

Fig. 9

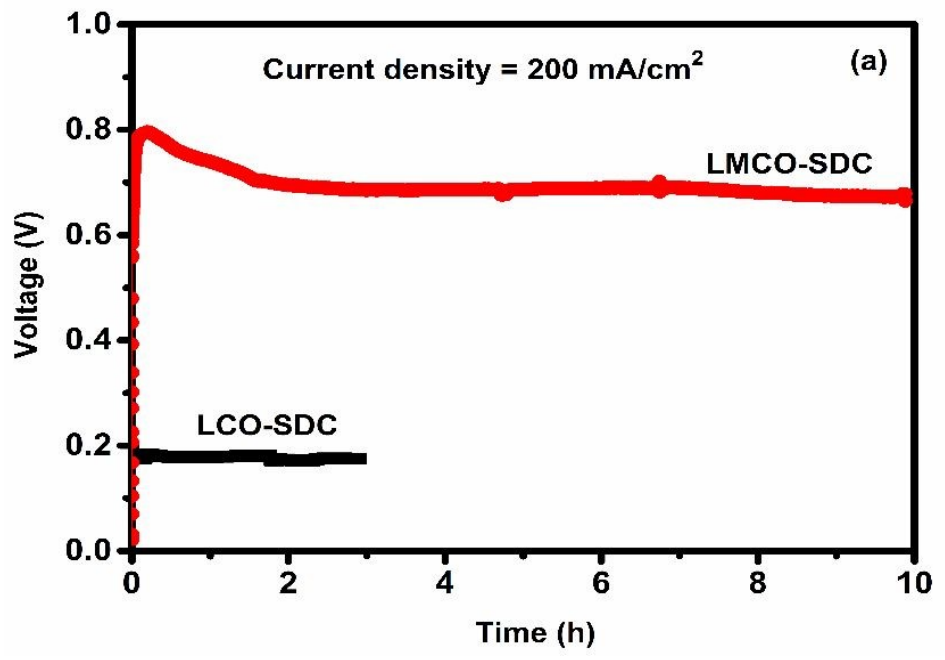

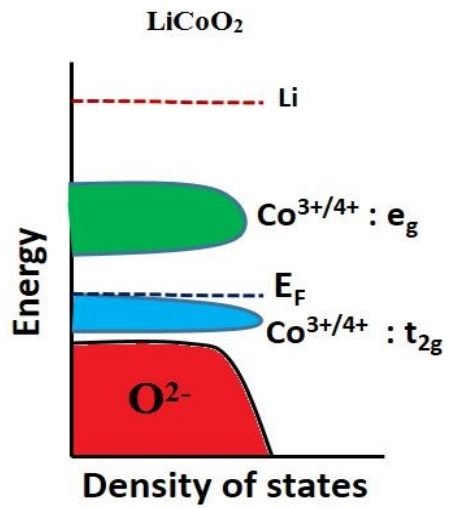

(b)

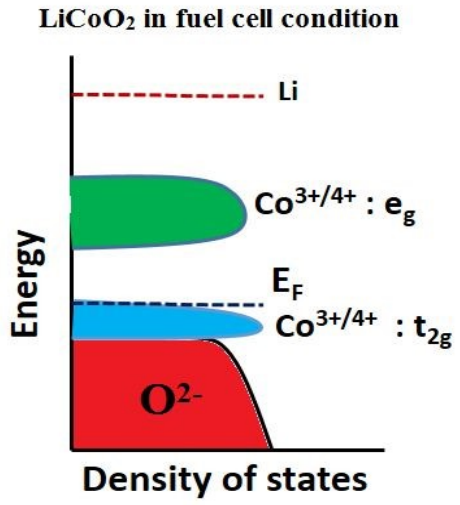

(c)

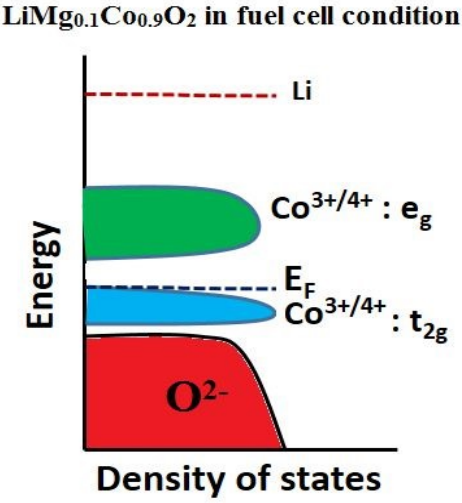

(d) 
Fig. 10

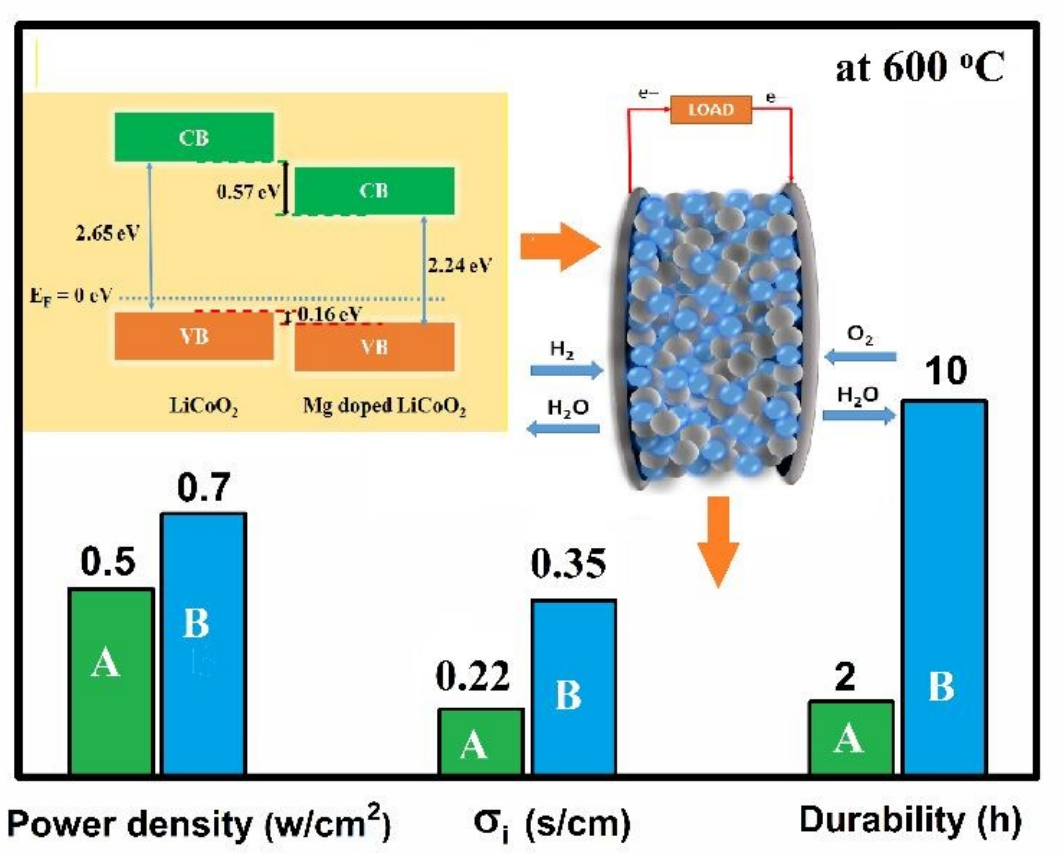

Table. 1 The ionic and electronic conductivity variations with temperature

\begin{tabular}{|c|c|c|c|c|}
\hline \multirow{2}{*}{ Temparature $\left({ }^{\circ} \mathrm{C}\right)$} & \multicolumn{2}{|c|}{ LCO-SDC (S/cm) } & \multicolumn{2}{c|}{ LMCO-SDC (S/cm) } \\
\cline { 2 - 5 } & $\sigma_{i}$ & $\sigma_{e}$ & $\sigma_{i}$ & $\sigma_{e}$ \\
\hline 600 & 0.22 & 0.142 & 0.35 & 0.4 \\
\hline 550 & 0.143 & 0.03 & 0.22 & 0.242 \\
\hline 500 & 0.06 & 0.003 & 0.132 & 0.126 \\
\hline
\end{tabular}

